\title{
METODE MENGHILANGKAN CAIRAN BUAH TOMAT DALAM UJI PERKECAMBAHAN BIJI TOMAT( Lycopersicum esculentum Mill.)
}

\section{METHOD OF TOMATO LIQUID ERASING ON TOMATO SEED GERMINATION TEST (Lycopersicum esculentum Mill.)}

\author{
Pesta Santi Nababan ${ }^{1}$, Tundjung T. Handayani ${ }^{1}$, Martha L. Lande ${ }^{1}$ \\ ${ }^{1}$ Jurusan Biologi FMIPA, Universitas Lampung \\ e-mail : tundjung@unila.ac.id \\ Jurusan Biologi FMIPA Universitas Lampung \\ Jl. Prof.Dr. Soemantri Brojonegoro No. 1, Bandar Lampung, Lampung, Indonesia, 35145
}

\begin{abstract}
Abstrak
Budidaya tanaman tomat tidak terlepas dari ketersediaan bibit yang baik yang berasal dari biji yang berkualitas sebagai benih. Dalam penyediaan bibit di lapangan, petani tomat lebih senang menggunakan biji tomat dari toko-toko pertanian walaupun harganya lebih mahal dibandingkan dengan menyediakan sendiri. Penyediaan biji sendiri selain memerlukan waktu yang lebih lama juga daya perkecambahannya rendah karena di bagian luar biji tomat terdapat cairan buah yang dapat menghambat perkecambahan biji sehingga tidak menghasilkan bibit yang maksimal. Dengan demikian, perlu dicari metode yang tepat untuk menghilangkan cairan buah tomat pada biji. Penelitian ini dilaksanakan di Laboratorium Botani FMIPA Universitas Lampung, dari bulan Agustus- September 2012. Percobaan dirancang secara Acak Lengkap (RAL) dengan 8 perlakuan diulang sebanyak 4 kali. Parameter yang diukur adalah persentase perkecambahan dan kecepatan perkecambahan. Data yang diperoleh diuji homogenitas kemudian dilakukan uji ANARA dan dilanjutkan dengan uji lanjut Duncan pada taraf $\alpha=5 \%$. Hasil penelitian menunjukkan bahwa: metode yang tepat untuk menghilangkan cairan buah tomat yang menyelubungi biji tomat adalah dengan cara dicuci dan dikeringkan.
\end{abstract}

Kata kunci : Cairan buah tomat, Lycopersicum esculentum, perkecambahan

\begin{abstract}
High quality tomato seed is the main prerequisite to produce high quality young plant for planting. In fact farmer prefer to germinate commercial tomato seed rather than seeds prepare by their own selves. The main reasons are time and the low germination capacity caused by fruit liquid in the outer of tomato seed that can inhibit tomato seed germination. The research is designed for finding the best method to remove tomato fruit liquid at the Botany Laboratory of FMIPA Lampung University from August to September of 2012. This research used complete Random desain using eight treatment with for replication for each treatment. Parameter which is measured are percentage of seed germinating rate. Data from the research are tested with homogenity test and followed by analysis of variance. The significant different among the datas will be tested by Duncan test with $\alpha=5 \%$. The research results showed that the right method for removing tomato liquid which covers tomato seed is by washing and drying.

Keywords : tomato seed, Lycopersicum esculentum, germination
\end{abstract}

\section{PENDAHULUAN}

Buah tomat mempunyai banyak manfaat terutama untuk menjaga kesehatan tubuh manusia. Selain mengandung gula (glukosa dan fruktosa), protein dan lemak, buah tomat banyak mengandung vitamin (Maulida dan Zulkarnaen, 2006). Budidaya tanaman tomat tentunya tidak terlepas dari kualitas biji tomat yang baik (Sotopo, 2002).
Bibit yang baik tergantung pada ketersediaan biji yang berkualitas sebagai benih. Dalam penyediaan bibit, petani lebih senang menggunakan biji tomat dari toko pertanian walaupun harganya lebih mahal. Hal ini karena penyediaan biji sendiri selain memerlukan waktu lebih lama juga ada kendala lain, yaitu biji yang langsung dikecambahkan dari buah tomat yang matang, daya perkecambahannya rendah karena di bagian luar biji terdapat cairan buah tomat yang diduga dapat menghambat perkecambahan biji tomat sehingga 
tidak menghasilkan bibit yang maksimal (Kamil, 1992).

\section{BAHAN dan METODE}

Metode yang digunakan dalam penelitian adalah metode eksperimen dengan Rancangan Acak Lengkap dengan 8 perlakuan 4 kali ulangan. Data yang diperoleh dianalisis ragam dengan taraf nyata $5 \%$ dan diuji lanjut dengan uji Duncan pada taraf $5 \%$. Perlakuan yang digunakan berupa P1) kontrol; P2) biji dicuci, dikeringkan, dan ditambah aquades; P3) biji dicuci, tidak dikeringkan, dan ditambah aquades; P4) biji tidak dicuci, dikeringkan, dan ditambah aquades; P5) biji tidak dicuci, tidak dikeringkan, dan ditambah aquades; P6) biji tidak dicuci, tidak dikeringkan, dan ditambah cairan buah tomat $10 \%$; P7) biji tidak dicuci, tidak dikeringkan, dan ditambah cairan buah tomat $20 \%$; dan P8) biji tidak dicuci, tidak dikeringkan, dan ditambah cairan buah tomat $30 \%$.

Parameter yang diamati dalam penelitian ini adalah persentase perkecambahan yang dihitung pada hari ke 10 dan kecepatan perkecambahan. Adapun rumus yang digunakan untuk menghitung nilai tersebut adalah :

Persentase perkecambahan (Sutopo, 1988) :

$\mathrm{PP}=\frac{\sum \text { benih yang berkecambah }}{\sum \text { benih yang dikecambahkan }} \times 100 \%$

Kecepatan perkecambahan (Pramono, 2010) :

$K P=\sum_{i=1}^{i=10} \frac{P i}{T i}$

Keterangan :

$\mathrm{KP}=$ kecepatan perkecambahan

$\mathrm{Pi}=$ Pertambahan persen perkecambahan dari hari ke

$\mathrm{Ti}$ = banyak hari sejak dikecambahkan sampai hari ke $\mathrm{i}, \quad\{\mathrm{i}=1,2,3 \ldots, \mathrm{n}\}$

Penyediaan biji tomat. Buah tomat lokal segar yang diperoleh dari pasar lokal dipilih sehingga diperoleh tingkat kemasakan dan warna yang sama lalu dicuci bersih dengan air. Buah dipotong lalu biji dipisahkan dari daging buah. Selanjutnya biji yang sudah terpisah dari daging buah diletakkan di atas saringan teh untuk diambil cairan buahnya. Biji yang telah terpisah dari cairan buah ada yang dicuci dan dikeringkan, dicuci tidak dikeringkan, tidak dicuci dikeringkan, dan tidak dicuci juga tidak dikeringkan.
Penyediaan Media Perkecambahan. Media yang digunakan untuk mengecambahkan biji tomat adalah kertas merang dengan ukuran $20 \mathrm{x}$ $25 \mathrm{~cm}$ dan lembaran plastik dengan ukuran dan jumlah yang sma.

Mengecambahkan Biji Tomat. Kertas merang sebanyak 64 potong dipersiapkan menjadi 32 satuan percobaan lalu dibasahi dengan ketentuan apabila kertas merang diangkat dengan posisi berdiri tidak ada air yang menetes ke bawah. Kemudian diletakkan di atas selembar plastik yang sudah dipersiapkan. Selanjutnya di atas kertas merang ditaruh sebanyak 20 biji sebagai satu satuan percobaan yang disusun dalam satu deretan sesuai dengan perlakuan masing-masing. Kertas merang dengan plastiknya yang telah digulung, diikat dengan karet galeng dan diberi label. Gulungan kertas merang diletakkan di dalam botol kecil dengan posisi berdiri dan diberi aquades setinggi $1,5 \mathrm{~cm}$ agar kelembaban kertas merang tetap terjaga dan diletakkan sesuai dengan skema letak satuan percobaan.

\section{HASIL dan PEMBAHASAN}

Hasil penelitian menunjukkan bahwa cairan buah tomat mempengaruhi perkecambahan biji tomat. Hal ini dapat dilihat dari hasil analisis ragam pada $\alpha=5 \%$ bahwa perlakuan cairan buah tomat yang diberikan pada biji tomat berpengaruh nyata terhadap persentase perkecambahan biji tomat dan juga berpengaruh nyata terhadap kecepatan perkecambahan biji tomat.

Uji lanjut persentase perkecambahan biji tomat dapat dilihat pada Tabel 1 dan Gambar 1.

Tabel 1. Rerata persentase perkecambahan biji tomat 10 hari setelah perlakuan dalam $\%$.

\begin{tabular}{|c|c|c|c|}
\hline $\begin{array}{c}\text { Perlak } \\
\text { uan }\end{array}$ & $\begin{array}{c}\text { Transfor } \\
\text { masi } \sqrt{x}\end{array}$ & $\begin{array}{c}\text { Data asli } \\
\text { persentase } \\
\text { perkecambahan biji } \\
\text { tomat (\%) }\end{array}$ & $\mathrm{a}=5 \%$ \\
\hline P1 & $10 \mathrm{a}$ & $100,00 \pm 0 \mathrm{a}$ & 1,30 \\
\hline P2 & $9,2 \mathrm{a}$ & $85,00 \pm 0 \mathrm{a}$ & 1,28 \\
\hline P3 & $7,5 \mathrm{~b}$ & $57,50 \pm 0,43 \mathrm{~b}$ & 1,27 \\
\hline P4 & $7,3 \mathrm{bc}$ & $55,00 \pm 0,96 \mathrm{bc}$ & 1,25 \\
\hline P5 & $6,5 \mathrm{~cd}$ & $43,70 \pm 0,54 \mathrm{~cd}$ & 1,22 \\
\hline P6 & $5,7 \mathrm{~d} \mathrm{~d}$ & $33,70 \pm 0,55 \mathrm{~d}$ & 1,19 \\
\hline P7 & $4,4 \mathrm{e}$ & $20,00 \pm 0,4 \mathrm{e}$ & 1,13 \\
\hline P8 & $3,6 \mathrm{f}$ & $16,20 \pm 1,7 \mathrm{f}$ & \\
\hline
\end{tabular}

Keterangan : angka yang diikuti dengan huruf yang sama menunjukkan tidak berbeda nyata pada taraf $a=5 \%$ 
Dari hasil uji lanjut terlihat bahwa perlakuan P1 (kon-trol) memiliki persentase perkecambahan terting-gi (100\%) tetapi pengaruhnya tidak menunjukkan perbedaan yang nyata terhadap perlakuan P2 (85\%), namun terhadap perlakuan P3, P4, P5, P6, P7, dan P8 pengaruhnya memberikan perbe-daan yang nyata. Persentase perkecaabahan yang paling rendah $(16,2 \%)$ diperoleh pada perlakuan P8 dan pengaruhnya memberikan per-bedaan yang nyata terhadap $\mathrm{P} 1$, P2, P3, P4, P5, P6, dan P7. Sedangkan untuk P3 (57\%) dengan P6 (33,7\%), masing-masing pengaruhnya tidak memberikan perbedaan yang nyata. Namun antara P3, P4, P5, dan P6 pengaruhnya mem-berikan perbedaan yang nyata terhadap P7(20\%) dan P8 (16,2\%).

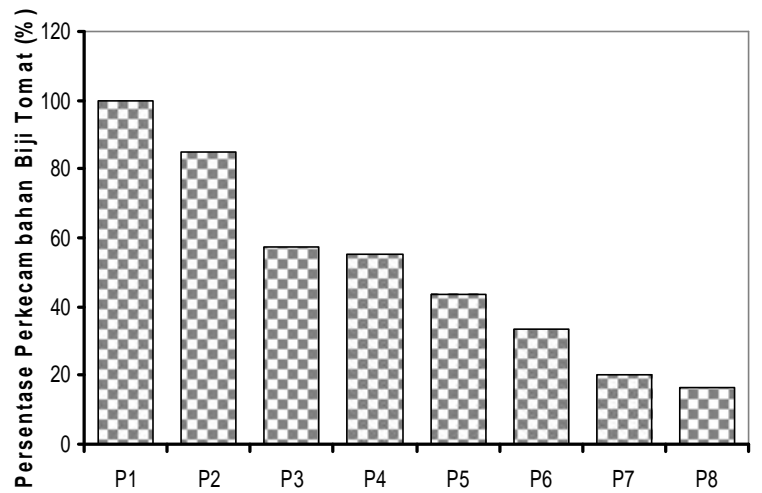

Gambar 1. Rerata persentase perkecambahan biji tomat 10 hari setelah perlakuan dalam \%.

Dari hasil uji lanjut menguatkan bahwa cairan buah tomat mempengaruhi persentase perkecambahan biji tomat. persentase perkecambahan tertinggi diperoleh pada perlakuan P1 (100\%) namun pengaruhnya tidak memberikan perbedaan yang nyata dengan perlakuan P2 (85\%) . Hal ini diduga karena biji-biji tomat yang digunakan pada P1 dan P2 sama-sama terbebas dari senyawa likopen yang terdapat pada cairan buah tomat yang menyelubungi biji tomat, sehingga air mudah berimbibisi ke dalam biji tomat, akibatnya perkecambahan biji-biji tomat pada P1 dan P2 tidak terhambat. Disamping itu biji-biji tomat yang digunakan pada $\mathrm{P} 1$ dan $\mathrm{P} 2$ mempunyai viabilitis yang baik. Heydecker (1972), meyatakan bahwa viabilitas biji ditentukan oleh kemampuan biji untuk berkecambah.

Dukungan lain dikemukakan oleh Kartasoeputra (2003), bahwa likopen adalah suatu senyawa yang bersifat hidrofobik yang menyebabkan air sulit berimbibisi kedalam biji tomat, sehingga dapat menghambat proses perkecambahan. Likopen juga dapat didegradasi melalui proses pen- cucian dan oksidasi, salah satunya dengan pengeringan. Selain terbebas dari likopen, biji-biji pada P1 dan P2 mempunyai potensial air yang rendah sehingga pada saat diberi air dalam hal ini aquades maka biji-biji tomat pada P1 dan P2 langsung berimbibisi sehingga biji-biji tomat pada P1 dan P2 dapat menunjukkan kemampuan perkecambahan yang baik dengan persentase perkecambahan $100 \%$ dan $85 \%$, sedangkan pada P3, P4, P5, P6, P7, dan P8 tidak demikian, walaupun biji-biji tomat pada P3-P8 mempunyai viabilitas yang baik dan sudah dicuci tetapi karena tidak dikeringkan maka proses degradasi likopen kurang maksimal dan potensial air juga masih agak tinggi (P3). Dan apabila biji-biji tomat dikeringkan tetapi tidak dicuci maka likopen masih dapat menghambat imbibisi air kedalam biji tomat (P4), terlebih pada biji-biji tomat yang tidak dicuci tidak dikeringkan (P5) tentunya senyawa likopen tidak hilang dan tidak rusak ditambah lagi cairan buah tomat pada P6, P7, P8, hal ini akan semakin menghambat proses imbibisi air kedalam biji-biji tomat, karena disamping senyawa likopen tidak rusak jumlah senyawa likopen yang dikandung semakin banyak, kondisi tersebut diatas menyebabkan persentase perkecambahan biji tomat semakin menurun dimulai dari P4 (43,7\%) sampai dengan P8 (16,2\%).

Dugaan tersebut diatas didukung oleh pendapat Heydecker (1972) dan Green (1975), menyatakan bahwa kemampuan perkecambahan suatu biji ditunjukkan oleh viabilitas biji tersebut dan biji tersebut terbebas dari zat yang bersifat penghambat seperti likopen dan juga kondisi biji tersebut memiliki potensial air yang rendah dengan cara mengeringkan biji-biji tersebut (Kuswanto, 1996).

Rendahnya persentase perkecambahan biji pada P8 (16,20\%) diduga bukan karena biji-biji tomat tersebut tidak viabel tetapi lebih disebabkan karena biji-biji tomat tersebut diselimuti cairan buah tomat yang semakin tinggi konsentrasinya sebab selain biji tidak dicuci tidak dikeringkan masih ditambah cairan buah tomat $30 \%$, sehingga bukan hanya air semakin sulit berimbibisi tetapi juga jumlah molekul air di dalam cairan buah semakin rendah. Bahkan pada perlakuan P8 muncul jamur disekitar biji-biji tomat yang tentunya dapat mengganggu perkecambahan biji tomat. Diduga kemunculan jamur disebabkan kandungan glukosa dalam cairan buah meningkat karena penambahan konsentrasi cairan buah tomat $30 \%$. Kondisi ini juga dapat menyebabkan persentase perkecambahan biji tomat semakin menurun. 
Selain hal tersebut diatas besar kemungkinan ada dugaan bahwa kumarin yang ada didalam cairan buah tomat masuk kedalam biji-biji tomat sehingga dapat menghambat transpor hormon giberelin, padahal hormon giberelin adalah hormon yang secara fisiologi memicu proses perkecambahan biji karena hormon giberelin berfungsi mengaktifkan enzim alfa amilase. Dugaan ini didukung oleh pendapat Einhellig (1995) dan Tweddle (2003), yang menyatakan bahwa kumarin adalah senyawa yang dapat menghambat transpor giberelin pada biji yang sedang berkecambah.

Uji lanjut kecepatan perkecambahan biji tomat dapat dilihat pada Tabel 2 dan Gambar 2. Dari hasil uji lanjut terlihat bahwa masing-masing perlakuan dari P1 sampai P8, menunjukkan pengaruh yang berbeda nyata antara perlakuan satu dengan perlakuan lainnya. Kecepatan perkecambahan tertinggi diperoleh pada perlakuan $\mathrm{P} 1$ (5,62\%/ hari), diikuti dengan P2 (4,75\%/ hari) dan seterusnya secara berurutan dan kecepatan perkecambahan paling rendah terdapat pada P8 $(1,93 \% /$ hari).

Tabel 2. Rerata kecepatan perkecambahan biji tomat 10 hari setelah perlakuan (\%/hari).

\begin{tabular}{|c|c|c|c|}
\hline Perlakuan & $\begin{array}{c}\text { Transforma } \\
\text { si } \sqrt{\mathrm{x}}\end{array}$ & $\begin{array}{c}\text { Rerata kecepatan } \\
\text { perkecambahan } \\
\text { (\%/hari) }\end{array}$ & $\begin{array}{c}\mathrm{a}= \\
5 \%\end{array}$ \\
\hline P1 & $31,76 \mathrm{a}$ & $5,62 \mathrm{a}$ & 0,2 \\
\hline P2 & $22,47 \mathrm{~b}$ & $4,75 \mathrm{~b}$ & 0,19 \\
\hline P3 & $19,51 \mathrm{c}$ & $4,40 \mathrm{c}$ & 0,19 \\
\hline P4 & $15,08 \mathrm{~d}$ & $3,82 \mathrm{~d}$ & 0,19 \\
\hline P5 & $10,95 \mathrm{e}$ & $3,29 \mathrm{e}$ & 0,18 \\
\hline P6 & $7,58 \mathrm{f}$ & $2,73 \mathrm{f}$ & 0,18 \\
\hline P7 & $5,13 \mathrm{~g}$ & $2,24 \mathrm{~g}$ & 0,17 \\
\hline P8 & $4,11 \mathrm{~h}$ & $1,93 \mathrm{~h}$ & \\
\hline
\end{tabular}

Keterangan : angka yang diikuti dengan huruf yang sama menunjukkan tidak berbeda nyata pada taraf $a=5 \%$

Dilihat dari hasil uji lanjut menunjukkan bahwa cairan buah tomat juga mempengaruhi kecepatan perkecambahan biji tomat, bahkan pengaruhnya menunjukkan perbedaan yang nyata untuk setiap perlakuan. Semakin tinggi konsentrasi cairan buah tomat cenderung semakin lambat kecepatan perkecambahannya.

Pada perlakuan P1 $(5,6 \% /$ hari) paling cepat perkecambahannya kemudian diikuti oleh P2 (4,7\%/hari), P3 (4,4\%/hari) dan seterusnya, dan kecepatan perkecambahan yang paling lambat terdapat pada perlakuan P8 (1,93\%/hari). Hal ini diduga biji-biji tomat yang digunakan pada P1 adalah biji-biji tomat yang mempunyai viabilitas yang baik terbebas dari zat penghambat (likopen), mempunyai potensial air yang rendah seperti yang dimiliki biji-biji tomat pada P2, namun karena biji-biji tomat pada P1 adalah bijibiji tomat yang berasal dari toko yaitu sudah melalui sertifikasi tentunya biji tomat pada $\mathrm{P} 1$ lebih memiliki vigor yang baik dibandingkan biji tomat pada P2, P3 sampai P8, sehingga kecepatan perkecambahan pada $\mathrm{P} 1$ lebih cepat daripada P2, P3, P4, P5, P6, P7, dan P8. Heydecker (1972), mengatakan bahwa biji yang memiliki vigor yang baik akan mempunyai kecepatan perkecambahan yang maksimal.

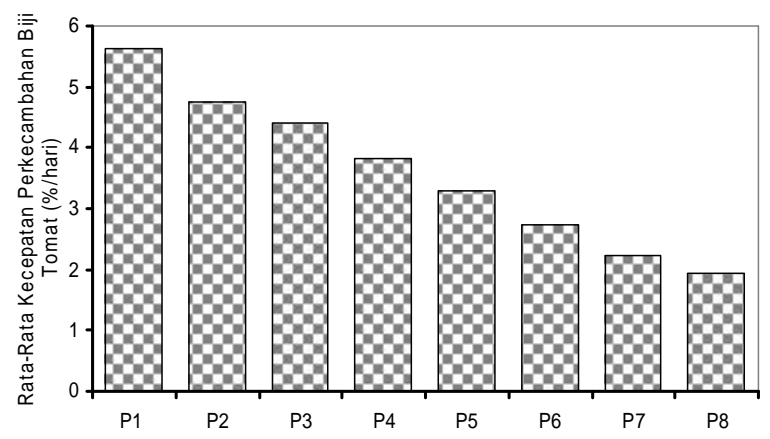

Gambar 2. Rerata kecepatan perkecambahan biji tomat 10 hari setelah perlakuan (\%/hari).

Walaupun kecepatan perkecambahan biji tomat pada P2 lebih lambat dibandingkan dengan kecepatan perkecambahan pada $\mathrm{P} 1$, namun jumlah biji yang berkecambah cenderung sama dengan jumlah biji pada P1 (100\%) dan P2 (85\%) sehingga dari segi ekonomis penggunaan biji-biji tomat pada P2 bisa direkomendasikan bagi para petani tomat untuk menyedikan biji tomat sendiri, dengan cara memilih biji tomat dari buah tomat yang masak secara fisiologi kemudian biji-biji tomat tersebut dicuci bersih dengan air sampai cairan buah hilang lalu dikeringkan di bawah panas matahari.

Kecepatan perkecambahan paling rendah terdapat pada P8 (1,93\%/hari). Hal ini diduga karena biji-biji tomat yang digunakan pada P8 bukan karena tidak viabel namun biji-biji tomat tersebut diselubungi oleh cairan buah yang makin tinggi konsentrasinya yaitu $30 \%$. Sehingga walaupun biji itu mempunyai kemampuan untuk berkecambah tetapi karena air yang diperlukan untuk berkecambah tidak bisa masuk, bahkan jumlah molekul air dalam cairan buah makin berkurang sehingga biji-biji tomat tersebut banyak yang tidak berkecambah dan proses perkecambahannya makin lambat terlebih ada praduga bahwa senyawa kumarin yang masuk kedalam biji- 
biji tomat yang menyebabkan transpor giberelin akan terhambat mengingat bahwa giberelin adalah hormon perangsang proses perkecambahan. Sudrajat (2011), menyatakan bahwa kumarin adalah zat yang dapat menghambat transpor giberelin.

\section{KESIMPULAN}

Berdasarkan hasil penelitian, dapat disimpulkan bahwa metode yang tepat untuk menghilangkan cairan buah tomat yang menyelubungi biji tomat yaitu dengan cara dicuci dan dikeringkan.

\section{DAFTAR PUSTAKA}

Einhellig, F. A. 1995. Allelopathy : Current Status ang Future Goals. In:Inderjit, K. M. M Dakshini and F. A. Einhellig. Symposium Series : Allelopathy Organism, Processes and Aplications. Washington DC.

Green, F.B. and M.R. Corcoran. 1975. Inhibitory Action of Five Tannins on Growth Induced by Several Gibberellin. Plant Physiol.

Heydecker, W. 1972. Vigour in Viability of Seed. Chapman and Hall Ltd. London.
Kamil, J. 1992. Teknologi Benih 1. Angkasa. Bandung

Kuswanto, H. 1996. Dasar-Dasar Teknologi, Produksi dan Sertifikasi Benih. Andi Ofset. Yogyakarta.

Kartasapoetra, A.G. 2003. Teknologi Benih. Rineka Cipta. Jakarta

Maulida, D. dan N. Zulkarnaen, 2006. Ekstraksi Antioksidan (Likopen) Dari Buah Tomat Dengan Menggunakan Solven Campuran, $n$ Heksana, Aseton, dan Etanol. Jurusan Teknik Kimia, Fakultas Teknik, Universitas Diponegoro. Semarang.

Sudrajat, J .D., Nurhasyi, and D. Syamsuwida. 2011. Technology to Improve Kepuh (Sterculia foetida Linn.). Seed Viability Vol 8 (5) :301-314

Sutopo, L. 1988. Teknologi Benih. Cetakan kedua. CV. Rajawali. Jakarta.

Sutopo, L. 2002. Teknologi Benih (Edisi Revisi). PT Raja Grafindo Persada. Jakarta.

Tweddle, J.C., J.B. Dickie, C.C Baskin, and J.M. Baskin. 2003. Ecological Aspects of Seed Desiccation Sensitivity. Journal of Ecology 91: 294-304. 